\title{
p53 protects against skin cancer induction by UV-B radiation
}

\author{
Weidong Jiang', Honnavara N Ananthaswamy'1, H Konrad Muller² and Margaret L Kripke*,1 \\ ${ }^{1}$ Department of Immunology, The University of Texas M.D. Anderson Cancer Center, 1515 Holcombe Boulevard, Box 178, \\ Houston, Texas, TX 77030, USA; ${ }^{2}$ Department of Pathology, University of Tasmania, 43 Collins Street, Hobart, Tasmania 7000, \\ Australia
}

\begin{abstract}
To assess the role of the $p 53$ tumor suppressor gene in skin carcinogenesis by UV radiation, mice constitutively lacking one or both copies of the functional p53 gene were compared to wild-type mice for their susceptibility to UV carcinogenesis. Heterozygous mice showed greatly increased susceptibility to skin cancer induction, and homozygous p53 knockout mice were even more susceptible. Accelerated tumor development in the heterozygotes was not associated with loss of the remaining wild-type allele of $p 53$, as reported for tumors induced by other carcinogens, but in many cases was associated with UV-induced mutations in p53. Tumors arose on the ears and dorsal skin of mice of all three genotypes, and homozygous knockout mice also developed ocular tumors, mainly melanomas. Skin tumors in the p53 knockout mice were predominately squamous cell carcinomas and were associated with premalignant lesions resembling actinic keratoses, whereas those in the heterozygous and wild-type mice were mainly sarcomas. These results demonstrate the importance of p53 in protecting against $\mathrm{UV}$-induced cancers, particularly in the eye and epidermis.
\end{abstract}

Keywords: sunlight; photocarcinogenesis; transgenic mice; tumor suppressor gene; mutation

\section{Introduction}

The p53 tumor suppressor gene codes for a DNAbinding protein involved in both cell cycle arrest and apoptosis. In response to DNA damage, p53 accumulates in cells, translocates to the nucleus, activates gene transcription, and ultimately results in cell cycle arrest, which is thought to permit repair of damaged DNA prior to cell replication (Hartwell and Weinert, 1989). In addition, p53 activates a pathway of programmed cell death, presumably in cells with excessive DNA damage (Lane, 1992). Perturbation of either pathway is expected to contribute to neoplastic transformation by permitting replication or survival of cells with DNA damage. This prediction is supported by many reports of cancers in which p53 is mutated or lost (Hollstein et al., 1991) and by the high incidence of malignancies in people with $\mathrm{Li}-$ Fraumeni syndrome, who inherit a mutation in one allele of p53 (Malkin et al., 1990).

In UV-associated skin carcinogenesis in both humans and mice, mutations in p53 are present with very high

*Correspondence: ML Kripke, Academic Programs, U.T.M.D. Anderson Cancer Center, 1515 Holcombe Blvd., Box 147, Houston, Texas, TX 77030, USA

Received 8 December 1998; revised 9 February 1999; accepted 5 March 1999 frequency (Brash et al., 1991; Kanjilal et al., 1993). Molecular analysis of the mutations demonstrated that most occur at dipyrimidine sites in DNA and therefore are very likely to have arisen from mutations induced by $\mathrm{UV}-\mathrm{B}(280-320 \mathrm{~nm})$ radiation in the $p 53$ gene itself. In experimental animals, such mutations in $p 53$ occur early in the course of UV irradiation, before tumors are grossly detectable (Ananthaswamy et al., 1997), and they have been found in chronically sun-damaged human skin as well (Nakazawa et al., 1994). These observations suggest that mutations in p53 are an important initial step in dysregulation of epidermal cell growth in the pathway leading to malignancy. However, the relative importance of this gene to the entire process of skin carcinogenesis is difficult to assess by simply examining its mutation frequency in the resulting tumors. Moreover, sunlight-associated skin cancers have not been noted to occur with increased frequency in persons with Li-Fraumeni syndrome (Malkin et al., 1990).

A direct approach for testing the hypothesis that p53 plays a critical role in preventing skin cancer induction by $\mathrm{UV}$ radiation is to irradiate mice lacking one or both functional copies of $p 53$. The development of such knockout mice has provided a new tool for investigating the role of p53 in the development of a variety of cancers. Both heterozygous $(+/-)$ and homozygous $(-/-)$ p53 null animals develop a spectrum of spontaneous tumors, primarily lymphoid malignancies and various types of sarcomas (Donehower et al., 1992; Jacks et al., 1994). The frequency of these tumors is greatly enhanced by exposing the animals to a single dose of ionizing radiation (Kemp et al., 1994), but even in such mice, skin cancers do not occur. In addition, in studies of skin cancer induction using a chemical initiation-promotion protocol, p53 +/- and -/mice did not show increased susceptibility to papilloma induction, although the progression from papilloma to carcinoma was enhanced compared to that in wild-type $(+/+)$ mice $($ Kemp et al., 1993). In spite of the strong association between p53 mutations and UV-induced skin cancers, no studies to date have examined the role of p53 in UV carcinogenesis using congenic p53-/mice. Therefore, we investigated the rate of skin cancer development in UV-irradiated, C57BL/6 congenic p53-/-, $+/-$, and $+/+$ mice, the spectrum of tumors produced, and the loss of the functional p53 allele in tumors from $+/-$ mice.

\section{Results}

\section{$U V$ carcinogenesis in p53+/ - and $+/+$ mice}

In a pilot experiment, 11 p53 heterozygous and ten wild-type littermates from the sixth backcross genera- 
tion onto the C57BL/6 strain were exposed to UV radiation. The animals were shaved weekly and exposed to an average of $13.3 \mathrm{~kJ} / \mathrm{m}^{2} \mathrm{UV}-\mathrm{B}$ radiation three times per week for 30 weeks. Most $p 53+/-$ mice developed skin or eye tumors within this period, with a median latency of 22 weeks (range $=18-28$ weeks), whereas no tumors developed in the wild-type mice during the 48th week of observation (Figure 1). No spontaneous tumors of internal organs developed in the $+/-$ mice during this experiment. Table 1 (Experiment A) shows that nine of the $11+/-$ mice developed tumors, six of them on more than one site, giving a total of 15 tumors. The most frequent site of occurrence was the ears $(67 \%)$, followed by skin on the back, head, or forepaw $(20 \%)$, and the eyes $(13 \%)$. Histological analysis revealed that $33 \%$ of the tumors were squamous cell carcinomas, $40 \%$ were sarcomas, and $20 \%$ were melanomas. No papillomas developed, which is in agreement with our previous observation that papillomas are rarely induced by chronic UV irradiation of haired mice (Kripke, 1977). This preliminary study indicated that $p 53+/-$ mice were highly sensitive to UV carcinogenesis and that, in spite of the long latency of these tumors, they could be induced before spontaneous tumors appeared.

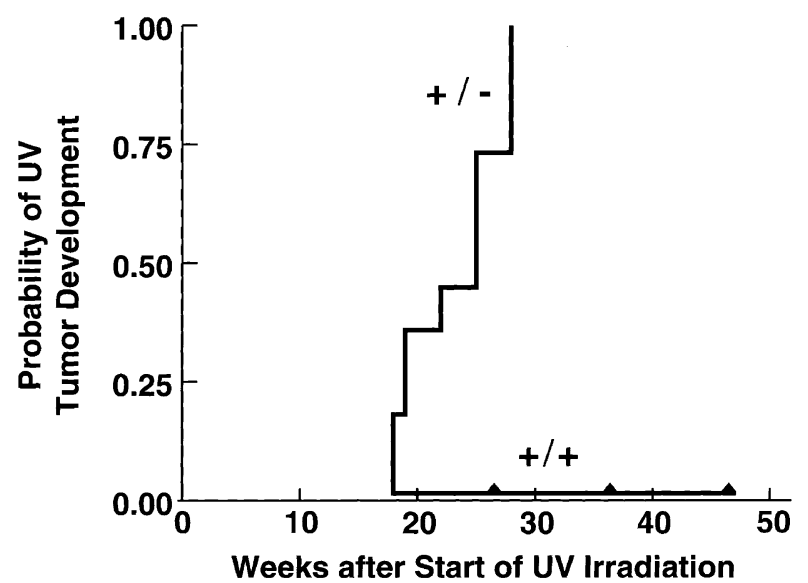

Figure 1 Probability of UV-induced tumor development in $p 53+/-$ and $+/+$ mice. Female mice in the 6 th backcross generation onto the $\mathrm{C} 57 \mathrm{BL} / 6$ strain were exposed on shaved dorsal skin to $13 \mathrm{~kJ} / \mathrm{m}^{2} \mathrm{UV}-\mathrm{B}$ three times per week for 30 weeks
$U V$ carcinogenesis in congenic p53-/-, +/-, and $+/+$ mice

To carry out a comparative carcinogenesis experiment in mice lacking one or two functional p53 alleles, it was necessary to produce congenic mice that differed only at the p53 locus. We therefore backcrossed mice with the mutant p53 allele onto the $\mathrm{C} 57 \mathrm{BL} / 6$ parental strain. Mice in the 8th backcross generation were indistinguishable from C57BL/6 mice by isoenzyme analysis, and mice tested in the tenth backcross generation were histocompatible based on second-set skin grafting. Cohorts of $-/-,+/-$, and $+/+$ littermates from the 12th backcross generation were exposed to UV-B radiation three times per week for 30 weeks, beginning at 12 th week of age and continuing until the mice developed tumors or died. The dose was reduced to $5 \mathrm{~kJ} / \mathrm{m}^{2} \mathrm{UV}-\mathrm{B}$ in this experiment because the dose used in the pilot experiment $\left(13 \mathrm{~kJ} / \mathrm{m}^{2} \mathrm{UV}-\mathrm{B}\right)$ was lethal to the $-/-$ mice. The rate of development of UVassociated tumors (skin or ocular) in mice of the three genotypes is shown in Figure 2. The data are presented as the probability of tumor development versus time after initiation of UV irradiation, using a life-table analysis, which permits the inclusion of animals that die during the experiment from other causes. The probability of $50 \%$ tumor development occurred at 14 weeks for the $-/-$ mice, 24 weeks for the $+/-$ mice, and 46 weeks for the $+/+$ mice.

The number and types of tumors that developed in the three groups are shown in Table 1B. Of $34-/-$ mice in the study, 16 developed a total of 27 skin or ocular tumors; all of these mice also had lymphoma or leukemia at the time of death. Of the remaining 18 mice, 16 died between weeks 6 and 23 (at 18-34 weeks of age) with lymphoma or leukemia, and two died at weeks 15 and 20 of unknown causes. A similar spectrum of UV-associated tumors developed in the $+/-$ mice, but these mice had fewer ocular tumors $(P<0.01$, Chi-square test $)$ and more tumors of dorsal skin than the $-/-$ mice. In this group, five mice died of unknown causes and one died of lymphoma between weeks 17 and 38 . The C57BL $/ 6+/+$ mice developed no ocular tumors $(P<0.02$ vs $-/-$ mice $)$, and the majority of tumors arose on dorsal trunk skin, rather than on the ears. Eleven mice in this

Table 1 Site and type of tumors induced by UV irradiation in $p 53-/-,-/+$, and $+/+$ mice

\begin{tabular}{|c|c|c|c|c|c|c|c|c|c|c|c|}
\hline & Genotype & $\begin{array}{c}\text { No of } \\
\text { mice }\end{array}$ & $\begin{array}{c}\text { No with } \\
\text { tumor }\end{array}$ & $\begin{array}{c}\text { No } \\
\text { tumors }\end{array}$ & Site & No $(\%)$ & $S C C^{a}$ & Fibrosarcoma & Melanoma & $\begin{array}{c}\text { Other } \\
\text { sarcoma }\end{array}$ & $\begin{array}{l}\text { Mixed } \\
\text { tumors }\end{array}$ \\
\hline \multirow[t]{3}{*}{ A. Pilot study } & $+/-$ & 11 & 9 & 15 & Eye & $2(13)$ & 0 & 0 & 1 & 1 & 0 \\
\hline & & & & & Ear & $10(67)$ & 3 & 2 & 2 & 2 & 1 \\
\hline & & & & & Back & $3(20)$ & 2 & 0 & 0 & $1^{\mathrm{b}}$ & 0 \\
\hline \multirow[t]{13}{*}{ B. Cohort study } & & & & & Totals $(\%)$ & & $5(33)$ & $2(13)$ & $3(20)$ & $4(27)$ & $1(7)$ \\
\hline & $-1-$ & 34 & 16 & 27 & Eye & $11(41)$ & 0 & 1 & 6 & $4^{c}$ & 0 \\
\hline & & & & & Ear & $12(44)$ & 9 & 1 & 0 & $2^{c}$ & 0 \\
\hline & & & & & Back & $4(15)$ & 1 & 0 & 0 & 3 & 0 \\
\hline & & & & & Totals $(\%)$ & & $10(37)$ & $2(7)$ & $6(22)$ & $9(33)$ & 0 \\
\hline & $+/-$ & 31 & 25 & 34 & Eye & $3(9)$ & 0 & 0 & 1 & $1^{\mathrm{c}}$ & 1 \\
\hline & & & & & Ear & $18(53)$ & 2 & 11 & 1 & 0 & 4 \\
\hline & & & & & Back & $13(38)$ & 1 & 10 & 0 & 0 & 2 \\
\hline & & & & & Totals $(\%)$ & & $3(9)$ & $21(62)$ & $2(6)$ & $1(3)$ & $7(21)$ \\
\hline & $+/+$ & 24 & 13 & 15 & Eye & $0(0)$ & 0 & 0 & 0 & 0 & 0 \\
\hline & & & & & Ear & $3(20)$ & 2 & 1 & 0 & 0 & 0 \\
\hline & & & & & Back & $12(80)$ & 1 & 7 & 0 & 1 & 3 \\
\hline & & & & & Totals $(\%)$ & & $3(20)$ & $8(53)$ & $0(0)$ & $1(7)$ & $3(20)$ \\
\hline
\end{tabular}

${ }^{\mathrm{a}}$ Squamous cell carcinoma; ${ }^{\mathrm{b}}$ Tumor developed on forepaw; ${ }^{\mathrm{c}}$ One unclassified malignant tumor 
group remained alive and tumor-free at week 47 of the experiment.

Review of the histology of the cutaneous and ocular lesions revealed a high percentage of squamous cell carcinomas of the skin and ocular melanomas (Figure 3 ) in the p53 - / - mice (59\% compared to $15 \%$ and $20 \%$ in the $+/-$ and $+/+$ respectively, Table 1$)$. In addition, many p53 - / mice exhibited solar keratoses in the treated skin, similar to those found in UV-irradiated human skin and considered to be a premalignant lesion (7/16 skin specimens examined vs $1 / 31$ and $0 / 15$ in the heterozygotes and wild-type mice).

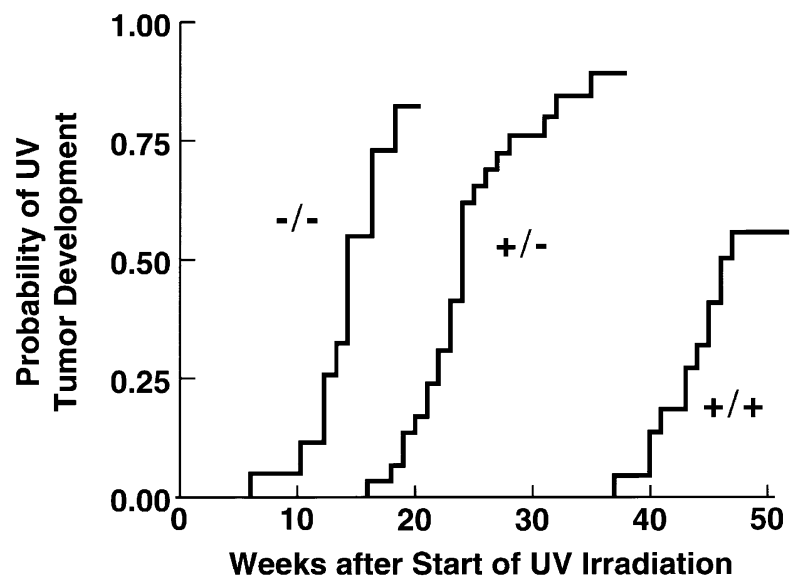

Figure 2 Probability of UV-induced tumor development in p53-/ $-+/-$, and $+/+$ mice. Cohorts of $\mathrm{C} 57 \mathrm{BL} / 6$ congenic mice of the three genotypes were exposed on shaved dorsal skin to $5 \mathrm{~kJ} / \mathrm{m}^{2} \mathrm{UV}$-B three times per week for 30 weeks
Premalignant dysplastic changes were also present in many of these specimens, and two of the squamous cell carcinomas were in situ lesions.

In contrast to the epithelial pathology observed in $-/-$ mice, sarcomas were mainly present in the $+/-$ $(65 \%)$ and $+/+(60 \%)$, with only $40 \%$ in the $-/-$ mice. The fibrosarcomas were confirmed by immunohistochemical staining using monoclonal antibodies to vimentin and keratin. Also interesting was the observation of combined fibrosarcoma and squamous cell carcinoma in the $+/-(21 \%)$ and $+/+(20 \%)$ mice. No mixed tumors are found in the $-/-$ group (Table 1).

In this experiment, we also included control groups of p53-/ - and $+/-$ mice without UV irradiation. The rate of incidence, and histopathology of internal tumor development (mainly lymphoid malignancies) were not altered by UV irradiation in $p 53-/-$ mice,

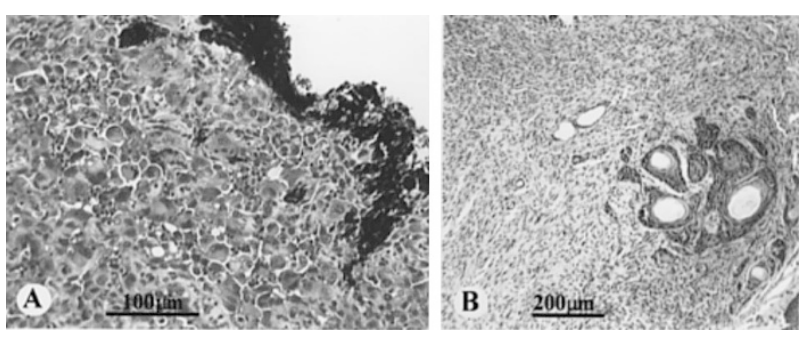

Figure 3 (a) Histological appearance of ocular melanoma from p53-/ - mouse. (b) Mixed tumor from p53+/- mouse, consisting of nests of squamous cell carcinoma within fibrosarcoma. Both types were confirmed with immunohistological stains for keratin and vimentin

Table 2 p53 mutations in UV-induced tumors from $p 53+/-$ mice

\begin{tabular}{|c|c|c|c|c|}
\hline Tumor & $\begin{array}{l}\text { Affected } \\
\text { exon }\end{array}$ & Codon & $\begin{array}{l}\text { Sequence } \\
\text { change }^{a}\end{array}$ & $\begin{array}{l}\text { Amino acid } \\
\text { change }\end{array}$ \\
\hline \multicolumn{5}{|l|}{ Pilot study ${ }^{b}$} \\
\hline A48-1 SCC & 5 & $157-158$ & $\mathrm{TACCGG} \rightarrow$ TAATGG & Met $\mathrm{Ala} \rightarrow$ Stop \\
\hline A58-2 Sarcoma & 5 & $157-158$ & $\mathrm{TA} \overline{\overline{\mathrm{CC}} \mathrm{GG}} \rightarrow \mathrm{TA} \overline{\overline{\mathrm{AT}} \mathrm{GG}}$ & Met $\mathrm{Ala} \rightarrow$ Stop \\
\hline \multicolumn{5}{|l|}{ Cohort study } \\
\hline G48 SCC & 5 & 143 & $\mathrm{ACC} \rightarrow \underline{\mathrm{ATT}}$ & $\operatorname{Trp} \rightarrow$ Stop \\
\hline G77 FS & 5 & 148 & $\underline{\mathrm{CCT}} \rightarrow \underline{\mathrm{TTT}}$ & Pro $\rightarrow$ Phe \\
\hline \multirow[t]{2}{*}{ G191 FS } & 5 & 148 & $\overline{\mathrm{CC}} \mathrm{T} \rightarrow \underline{\underline{\mathrm{TT}}}$ & Pro $\rightarrow$ Phe \\
\hline & & 155 & $\overline{\mathrm{C}} \underline{\mathrm{C}} \mathrm{GC} \rightarrow \overline{\mathrm{T}} \mathrm{GC}$ & $\mathrm{Arg} \rightarrow \mathrm{Cys}$ \\
\hline \multirow[t]{2}{*}{$\mathrm{G} 44-2 \mathrm{FS}+\mathrm{SCC}$} & 6 & 212 & $\mathrm{~A} \overline{\mathrm{G}} \underline{\mathrm{C}} \rightarrow \mathrm{A} \overline{\mathrm{G}} \underline{\mathrm{T}}$ & $\mathrm{Ser} \rightarrow \mathrm{Ser}$ \\
\hline & & 213 & DēetionGTG & Val \\
\hline G14-1 FS & 8 & 270 & $\mathrm{t} \underline{\mathrm{CGT}} \rightarrow \mathrm{t} \underline{\mathrm{T}} \mathrm{GT}$ & $\mathrm{Arg} \rightarrow \mathrm{Cys}$ \\
\hline G14-2 FS & 8 & 270 & $t \underline{\bar{C}} G T \rightarrow t \underline{\bar{T}} G T$ & $\mathrm{Arg} \rightarrow \mathrm{Cys}$ \\
\hline G25 Sarcoma & 8 & 270 & $\mathrm{t} \underline{\overline{\mathrm{C}}} \mathrm{GT} \rightarrow \mathrm{t} \underline{\mathrm{T}} \mathrm{GT}$ & $\mathrm{Arg} \rightarrow \mathrm{Cys}$ \\
\hline G35-1 FS + SCC & 8 & 270 & $t \underline{\bar{C}} G T \rightarrow t \underline{\bar{T}} G T$ & $\mathrm{Arg} \rightarrow \mathrm{Cys}$ \\
\hline G35-2 FS + SCC & 8 & 270 & $\mathrm{t} \underline{\mathrm{C}} \mathrm{GT} \rightarrow \mathrm{t} \underline{\mathrm{T}} \mathrm{GT}$ & $\mathrm{Arg} \rightarrow \mathrm{Cys}$ \\
\hline G42 Sarcoma & 8 & 270 & $\mathrm{t} \underline{\overline{\mathrm{C}}} \mathrm{GT} \rightarrow \mathrm{t} \underline{\mathrm{T}} \mathrm{GT}$ & $\mathrm{Arg} \rightarrow \mathrm{Cys}$ \\
\hline G44-1 SCC & 8 & 270 & $t \underline{\overline{\mathrm{C}}} \mathrm{GT} \rightarrow \mathrm{t} \underline{\overline{\mathrm{T}}} \mathrm{GT}$ & $\mathrm{Arg} \rightarrow \mathrm{Cys}$ \\
\hline G66 FS & 8 & 270 & $\mathrm{t} \underline{\overline{\mathrm{C}}} \mathrm{GT} \rightarrow \mathrm{t} \underline{\mathrm{T}} \mathrm{GT}$ & $\mathrm{Arg} \rightarrow \mathrm{Cys}$ \\
\hline G91 FS & 8 & 270 & $\mathrm{t} \underline{\overline{\mathrm{C}} \mathrm{GT}} \rightarrow \mathrm{t} \underline{\mathrm{T}} \mathrm{GT}$ & $\mathrm{Arg} \rightarrow \mathrm{Cys}$ \\
\hline G18 FS & - & & & \\
\hline G35-3 Sarcoma & - & & & \\
\hline G35-4 Sarcoma & - & & & \\
\hline G36 Melanoma & - & & & \\
\hline G49 FS & - & & & \\
\hline G54 FS & - & & & \\
\hline G60 FS & - & & & \\
\hline G96 FS & - & & & \\
\hline G178 FS & - & & & \\
\hline G202 FS & - & & & \\
\hline G253 FS & & & & \\
\hline
\end{tabular}

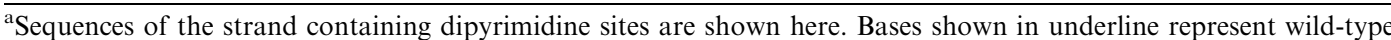
and corresponding mutated nucleotides. Affected codon shown in capital letters, and adjacent base shown in lowercase letters. ${ }^{b}$ Only exon 5 of the $p 53$ gene was analysed 
confirming the recent results of $\mathrm{Li}$ et al. (1998). However, in the p53 $+/-$ mice, the incidence of internal tumor development was significantly increased by UV irradiation (not shown).

\section{Status of wild-type p53 allele in $U V$-induced skin cancers}

Next we investigated whether skin cancer development was associated with loss of the wild-type p53 allele from the $+/-$ mice, as was the case for chemicallyinduced skin tumors (Kemp et al., 1993) and internal malignancies of $p 53+/-$ mice exposed to ionizing radiation (Kemp et al., 1994). Southern blot analysis of five paired samples of tumors and normal skin from the same animals revealed that both the wildtype and mutant alleles of p53 were present (Figure 4a). Ten additional UV-induced skin tumors from p53+/ - mice in the cohort study were also analysed by both Southern blotting and PCR. None of them lost the remaining wild-type allele of the p53 gene (not shown). Thus, of the 19 UV-induced tumors examined, including ten fibrosarcomas, three squamous cell carcinomas (SCC), three mixed tumors (fibrosarcoma and SCC), two suspected melanomas, and one hemangiosarcoma, none showed loss of heterozygosity.

To search for mutations in the wild-type allele of p53 in tumors from $p 53+/-$ mice, we performed PCR - SSCP analysis on 12 of the 13 skin tumors from the pilot study and 24 of the 31 skin tumors from the cohort study. From the pilot study, six of 12 were positive and from the cohort study 13 of 24 were positive, giving an overall mutation frequency of $53 \%$. Five of the 19 PCR-SSCP-positive tumors had alterations in exon 5. Because the mutant allele in the p53 knockout mice contains a large insert that extends into exon 5, the primers used to detect exon 5 amplify only the wild-type allele. Therefore, we were able to sequence directly the mutations in the wild-type copy of $p 53$. Seven mutations in exon 5 were detected in these five tumors (Table 2). All were $\mathrm{C} \rightarrow \mathrm{T}$ point mutations or $\mathrm{CC} \rightarrow \mathrm{TT}$ or $\mathrm{CC} \rightarrow \mathrm{AT}$ double tandem

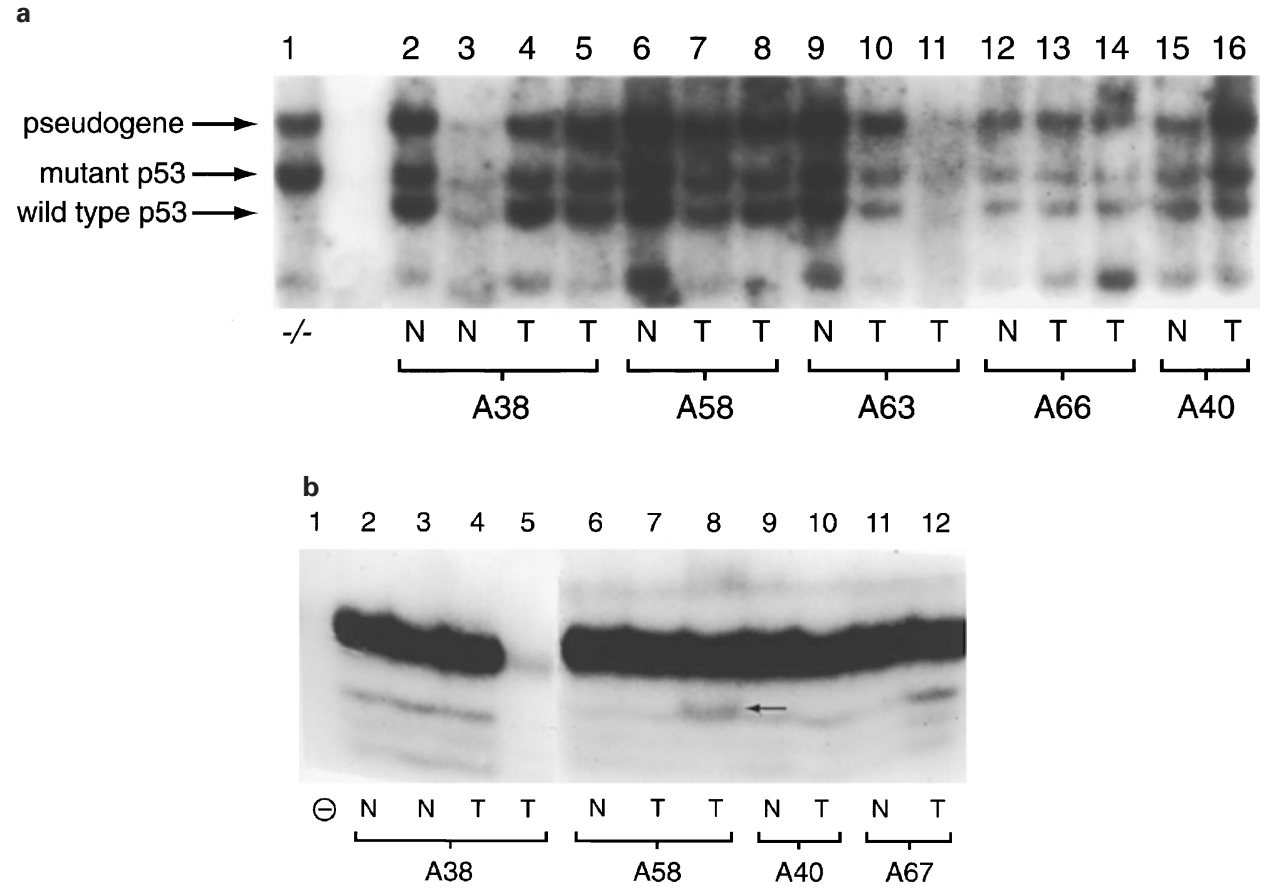

$\begin{array}{llllllllll}13 & 14 & 15 & 16 & 17 & 18 & 19 & 20 & 21 & \end{array}$

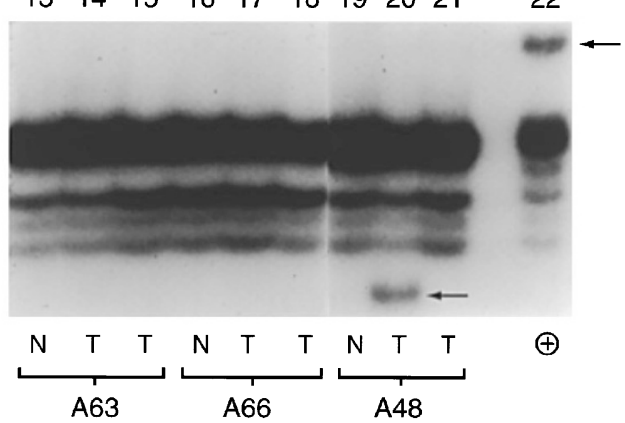

Figure 4 (a) Southern blotting analysis of BamHI-digested DNA from normal skin (N) or tumor (T) from UV-irradiated p53 + / mice. Lane 1, normal tissue from unirradiated $p 53-/-$ mouse. Lanes $2-5$, tissues from mouse \# 38; Lanes 6-8, tissues from mouse \# 58; Lanes 9-11, tissues from mouse \# 63; Lanes 12-14, tissues from mouse \# 66; Lanes 15-16, tissues from mouse \# 40. (b) SSCP analysis of $p 53$ exon 5 in UV-induced tumors from $p 53+/-$ mice. Lane 1 , negative control (no DNA); Lanes $2-5$, from mouse \# 38; Lanes 6-8, from mouse \# 58; Lanes 9-10, from mouse \# 40; Lanes 11 and 12 from mouse, \# 67; Lanes 13-15, from mouse \# 63; Lanes 16-18, from mouse \# 66; Lanes 19-21, from mouse \# 48; Lane 22, tumor \# 98.1 with known mutation in exon 5 (positive control). Arrows indicate shifted (mutant) bands 
mutations characteristic of those produced by UV radiation. Three mutations resulted in stop codons and four were missense mutations.

To sequence alterations in exons 6-8, pairs of primers were used that amplified only the wild-type allele. One primer was anchored in a region that was deleted in the inactive $p 53$ allele; the other spanned the intron-exon junctions of each exon examined. Abnormal bands from the SSCP gels were cut out, reamplified, and sequenced. Exons 6-8 were examined only in tumors from the cohort study. As shown in Table 2, of the 13 tumors with mutations, three occurred in exon 5 , one was in exon 6 , and nine were in exon $8(69 \%)$. All mutations in exon 8 were $\mathrm{C} \rightarrow \mathrm{T}$ point mutations at codon 270 , which is a mutational hotspot, resulting in an Arg $\rightarrow$ Cys substitution (Kanjilal et al., 1993; Ananthaswamy et al., 1998). The tumor with an alteration in exon 6 had a silent point mutation in codon 212, as well as a deletion of codon 213. There was no apparent difference in the histological types of tumors exhibiting mutations in p53 compared to those without detectable mutations (Table 2).

\section{Discussion}

These studies demonstrate the extreme sensitivity of p53-/ - and $+/-$ mice to tumor induction by UV radiation and indicate the critical nature of this gene in protecting against UV carcinogenesis. These results correlate well with the demonstration that $p 53-/-$ mice exhibit markedly reduced apoptosis (sunburn cell formation) in the epidermis after UV irradiation and $+/-$ mice show an intermediate response between $-/$ - and wild-type mice (Ziegler et al., 1994). Our results differ dramatically from those obtained in studies of chemical carcinogenesis using an initiation-promotion protocol (Kemp et al., 1993), in which tumor progression was enhanced, but the incidence of papillomas actually decreased. This suggests that p53 may play different roles in the evolution of chemicallyinduced and UV-induced skin tumors. Although this difference could be due to the disparate genetic backgrounds of the mice used in the two studies, it most likely reflects differences in the biology of the tumors produced during chemical and UV carcinogenesis. Whereas two-stage chemical carcinogenesis protocols induce mainly papillomas, some of which may regress or progress to invasive carcinomas, chronic UV irradiation of most haired, inbred strains of mice induces a variety of carcinomas and sarcomas and only an occasional papilloma (Kripke, 1977). Histological analysis of the tumors produced in this study showed that sarcomas predominated in mice with one or two copies of $p 53$, whereas squamous cell carcinoma predominated in $p 53-/-$ mice. This may indicate that p53 plays a more important role in regulating epidermal carcinogenesis than mesenchymal tumors. Another possibility is suggested by the finding that in chemically-induced tumors of $p 53+/-$ mice, the wildtype allele of p53 was lost (Kemp et al., 1993), whereas in the UV-induced tumors, the wild-type allele of p53 remained, and p53 mutations in this allele could be detected in approximately $50 \%$ of the tumors. All but one of the mutations were point mutations at dipyrimidine sites characteristic of UV-induced mutations. Thus, UV-induced mutation in $p 53$, rather than loss of the wild-type allele, was a frequent occurrence in UV carcinogenesis in the $p 53+/-$ mice. This difference could result from the fact that UV radiation generally causes point mutations rather than large deletions in DNA.

Since p53 plays such an important role in skin cancer development, it is curious that the $p 53-/-$ mice fail to develop spontaneous skin cancers, even though they develop other types of malignancy with very high frequency. The high rate of cellular proliferation in normal skin would seem to make it an obvious candidate for spontaneous transformation in the absence of $p 53$ function. The lack of such spontaneous skin cancers in these mice (Donehower et al., 1992; Jacks et al., 1994) suggests that $p 53$ plays a major role in the response of keratinocytes and other cells of the skin to UV-induced DNA damage and a less prominent or no role in the control of normal proliferation of this tissue. This suggestion is supported by a recent study showing that $p 53+/-$ mice lacking the $X P C$ gene, which is involved in repair of UVinduced DNA damage, are highly sensitive to the acute effects of UV radiation and exhibit increased susceptibility to UV carcinogenesis compared to XPC-/mice with wild-type $p 53$ (Cheo et al., 1996). However, this study is confounded somewhat by the mixed genetic background of the UV-irradiated mice.

An unexpected finding from this study was the high incidence of ocular tumors in the $p 53-/-$ mice, most of which were melanomas. Although such tumors occur occasionally in UV-irradiated $p 53+/+$ mice, their frequency was significantly increased in the absence of functional p53. Another surprising finding was the occurrence of cutaneous melanomas in both p53-/ - and $p 53+/-$ mice. Although in humans, cutaneous melanoma is often associated with sunlight exposure, mice rarely develop melanoma in response to UV radiation alone, chemical carcinogens usually being required as initiators or promoters of melanoma development in mouse skin (Donawho and Kripke, 1991). There may have been a higher incidence of cutaneous melanomas in the p53 deficient mice, but because of the small numbers, the differences were not statistically significant. In this regard, it is interesting to note that patients with $\mathrm{Li}-$ Fraumeni syndrome have an excess incidence of cutaneous melanoma, although there are no reports of excess non-melanoma skin cancers (Malkin et al., 1990). Whether this is because non-melanoma skin cancers are generally not reported or these patients do not exhibit the same increased sensitivity to UV carcinogenesis as the $p 53+/-$ mice is not clear. There is no evidence that ocular melanoma in humans is related to exposure to UV radiation (Kraemer et al., 1987); therefore, one would not expect to find an increased incidence of this tumor in people with $\mathrm{Li}$-Fraumeni syndrome.

In summary, our studies demonstrate the essential role of $p 53$ in protecting the skin against UV carcinogenesis and strengthen the notion that UVinduced mutations in p53 found in skin cancers represent molecular lesions that are of functional significance in the evolution of these tumors. In a recent study, we found that application of sunscreens to the skin of mice prior to UV irradiation greatly 
decreased the rate of appearance of $p 53$ mutations in non-tumorous skin (Ananthaswamy et al., 1997). The results reported here further support the concept that p53 mutations can serve as an early marker of skin cancer development and that the prevention of such mutations is an appropriate indicator of photoprotection.

\section{Materials and methods}

Mice

Specific-pathogen-free C57BL/6NCr mice were obtained from the Frederick Cancer Research Facility Animal Production Area. Specific-pathogen-free p53 knockout mice (TSG-p53) were obtained from GenPharm, Intl. (Mountain View, CA, USA) and backcrossed onto the C57BL/6 background. TSGp53 mice were derived from those originally produced by Donehower et al. (1992). The mice were housed in a pathogen-free barrier facility accredited by the American Association for Accreditation of Laboratory Animal Care, in accordance with current US Department of Agriculture, Department of Health and Human Services, and National Institutes of Health regulations and standards. All procedures were approved by the Institutional Animal Care and Use Committee. Mice were housed under filter-protected cages, and ambient lighting was controlled to provide $12 \mathrm{~h}$ light$12 \mathrm{~h}$ dark cycles. Autoclaved National Institutes of Health open formula mouse chow and water were provided ad libitum.

\section{UV irradiation}

UV radiation was provided by a bank of six FS40 sunlamps (National Biological Corp., Twinsburg, OH, USA), which emit a continuous broad spectrum from $250-400 \mathrm{~nm}$, with a peak emission at $313 \mathrm{~nm}$. Approximately $65 \%$ of the radiation is emitted within the UV-B $(280-320 \mathrm{~nm})$ range (Kripke, 1977); the incident dose-rate averaged $3.75 \mathrm{~W} / \mathrm{m}^{2}$ UV-B over the course of the experiments. For the cohort study, age-matched mice of the three genotypes were irradiated three times per week for 30 weeks, beginning at 12 weeks of age; all mice had their dorsal fur shaved weekly. All $-/-$ mice, $74 \%$ of the $+/-$, and $83 \%$ of the $+/+$ mice were males. Since there was no difference in the rate or site of tumor development or histological types of tumors between males and females, the data for males and females were pooled. Mice were individually numbered and observed three times per week for health status; skin lesions were measured weekly with a vernier caliper in two bisecting diameters.

\section{Southern hybridization}

Genomic DNA $(10 \mu \mathrm{g})$ was isolated from the tails of 1-weekold mice and cleaved with BamHI (Boehringer-Mannheim,

\section{References}

Ananthaswamy HN, Loughlin SM, Cox P, Evans RL, Ullrich SE and Kripke ML. (1997). Nature Med., 3, $510-514$.

Ananthaswamy HN, Fourtanier A, Evans RL, Tison S, Medaisko C, Ullrich SE and Kripke ML. (1998). Photochem. Photobiol., 67, 227-232.

Brash DE, Rudolph JA, Simon JA, Lin A, Mckenna GJ, Baden HP, Halperin AJ and Ponten J. (1991). Proc. Natl. Acad. Sci. USA, 88, $10124-10128$.

Cheo DL, Meira LB, Hammer RE, Burns DK, Doughty ATB and Friedberg EC. (1996). Curr. Biol., 6, 1691-1694.
Indianapolis, IN, USA). The DNA was subjected to electrophoresis for $18 \mathrm{~h}$ at $25 \mathrm{~V}$ in $0.8 \%$ agarose gel. The DNA was transferred to nitrocellulose paper $(0.45 \mu \mathrm{m}$ pore size) and hybridized with the $p 53$ exon $2-6$ probe supplied by GenPharm Intl. Positive bands were detected by autoradiography.

\section{DNA analysis}

Thirty nanograms of genomic DNA extracted from tumor and normal skin were used in each $25 \mu \mathrm{l}$ of the amplification reaction mixture. Exon 5 of the p53 gene was amplified by PCR using primers that spanned the intron-exon junctions, as described previously (Kanjilal et al., 1993; Ananthaswamy et al., 1998). For the amplification of exons 6-8, one primer was anchored in exons that were deleted in the targeted allele was used, along with a primer that spanned in the intronexon junctions of the desired exon. The identity of the PCR products was verified by running them on a $2 \%$ agarose gel.

\section{SSCP analysis}

SSCP analysis was performed using a mutation detection enhancement (MDE) gel (AT Biochem, Malvern, PA, USA). Briefly, the amplification reaction was performed in a $25 \mu \mathrm{l}$ volume in the presence of $2.5 \mu \mathrm{Ci}$ of $\left[\alpha{ }^{32} \mathrm{P}\right] \mathrm{dCTP}$, and $1.5 \mu \mathrm{l}$ aliquots of the products were diluted with $3.5 \mu \mathrm{l}$ of stop solution. The diluted PCR products were heated at $94^{\circ} \mathrm{C}$ for 4 min and quick-cooled and loaded onto $0.25 \times$ MDE gel and resolved by electrophoresis at $6 \mathrm{~W}$ for $16 \mathrm{~h}$ as described previously (Kanjilal et al., 1993). SSCP analyses were repeated three times.

\section{Nucleotide sequencing}

The abnormal bands were cut from the SSCP gels, dissolved in $100 \mu \mathrm{l}$ TE buffer containing $10 \mathrm{mM}$ Tris and $1 \mathrm{~mm}$ EDTA (pH 8.0), and heated at $80^{\circ} \mathrm{C}$ for $30 \mathrm{~min}$. The supernatants were purified by spinning through Microron-30 tubes (Amicon, Berkeley, CA, USA) and were used as templates for PCR amplification with specific primers. PCR products were sequenced directly in both directions using the Sequenase version 2.0 sequencing kit (USB, Cleveland, $\mathrm{OH}$, USA) according to the manufacturer's instructions. Normal mouse skin DNA and wild-type bands from SSCP gels were also amplified and sequenced along with the mutant bands.

\section{Acknowledgments}

We thank Clifton L Stephens, DVM, PhD for assistance with histopathological analysis of the tumor specimens. These studies were supported by NIH grants P01CA68233 (MLK), R01CA46523 (HNA), and CA16672 (Institutional core grant).

Donawho CK and Kripke ML. (1991). Cancer Metastasis Rev., 10, $177-188$.

Donehower LA, Harvey M, Slagle BL, McArthur MJ, Montgomery Jr CA, Butel JS and Bradley A. (1992). Nature, 356, 215-221.

Hartwell LH and Weinert TA. (1989). Science, 246, 629634.

Hollstein M, Sidransky D, Vogelstein B and Harris CC. (1991). Science, 253, 49-53. 
Jacks T, Remington L, Williams BO, Schmitt EM, Halachmi S, Bronson RT and Weinberg RA. (1994). Curr. Biol., 4, $1-7$.

Kanjilal S, Pierceall WE, Cummings KK, Kripke ML and Ananthaswamy HN. (1993). Cancer Res., 53, 2961 - 2964.

Kemp CJ, Donehower LA, Bradley A and Balmain A. (1993). Cell, 74, 813-822.

Kemp CJ, Wheldon T and Balmain A. (1994). Nature Genetics, 8, 66-69.

Kraemer KH, Lee MM and Scotto J. (1987). Arch. Dermatol., 123, 241-250.

Kripke ML. (1977). Cancer Res., 37, 1395-1400.

Lane DP. (1992). Nature, 358, 15-16.
Li G, Tron V and Ho V. (1998). J. Invest. Dermatol., 110, $72-75$.

Malkin D, Li FP, Strong LC, Fraumeni Jr JF, Nelson CE, Kim DH, Kassel J, Gryka MA, Bischoff FZ, Tainsky MA and Friend SH. (1990). Science, 250, $1233-1238$.

Nakazawa H, English D, Randell PL, Nakazawa K, Martel N, Armstrong BK and Yamasaki H. (1994). Proc. Natl. Acad. Sci. USA, 91, 360-364.

Ziegler A, Jonason AS, Leffell DJ, Simon JA, Sharma HW, Kimmelman J, Remington L, Jacks $\mathrm{T}$ and Brash DE. (1994). Nature, 372, $773-776$. 